\title{
Geospatial Assessment of Coseismic Landslides in Baturagung Area
}

\author{
Aditya Saputra ${ }^{1,2}$, Junun Sartohadi ${ }^{3}$, Danang Sri Hadmoko ${ }^{3}$, Christopher Gomez ${ }^{2}$ \\ ${ }^{1}$ Universitas Muhammadiyah Surakarta \\ ${ }^{2}$ University of Canterbury \\ ${ }^{3}$ Universitas Gadjah Mada \\ Corresponding E-mail: aditya.saputra@pg.canterbury.ac.nz
}

\begin{abstract}
Java, the most densely populated island in Indonesia, is located on top of the most seismically active areas in Southeast Asia: the Sunda Megathrust. This area is frequently hit by strong earthquake. More than 3,300 $M>$ 5earthquakesoccurred between 1973-2014. The wide range of mountainous areas and high intensity of rainfall, make several part of the island one of the most exposed regions for coseismic landslides such as Baturagung area, the Southeast mountainous area of Yogyakarta Province. An integrated method between RS and GIS was used to conduct the vulnerability assessment due to the lack of the site specific slope instability analysis and coseismic landslides data. The seismic zonation of Baturagung area was obtained based on the analysis of Kanai attenuation. The geologic information was extracted using remote sensing interpretation based on the 1:100,000 geologic map of Yogyakarta and geomorphologic map of Baturagung area as well. The coseismic landslide hazard assessment has been estimated using scoring analysis in the GIS platform proposed by Mora and Vahrson (1993) with several modifications. The accomplished coseismic landslide hazard map shows medium hazard coverage in the eastern areas, in the upper slope of Baturagung area, which consists of Semilir Formation. The result provides a distinct description of coseismic landslides hazard distribution in Batuaragung area. However, it should only be the preliminary assessment of the site specific investigation especially on valuable area or asset.
\end{abstract}

Keyword: Coseismic landslide hazard, geographic information system (GIS), Baturagung, hazard assessment

\begin{abstract}
Abstrak
Pulau Jawa, pulau terpadat di Indonesia, terletak sangat dekat dengan salah satu zona seismik aktif di Asia Tenggara yaitu megathrust Sunda. Area ini sangat rawan terhadap bahaya gempabumi besar. Lebih dari 3.300 gempabumi besar $(M>5)$ terjadi antara tahun 1973 hingga 2014. Karena kondisi fisik yang berdekatan dengan zona rawan gempabumi, adanya area perbukitan dan intensitas curah hujan yang sangat besar, maka beberapa area di Jawa merupakan zona rawan terjadinya longsor yang dipicu oleh gempabumi, misalnya area perbukitan di sebalah tenggara Provinsi Yogyakarta, atau sering disebut sebagai perbukitan Baturagung. Tidak tersedianya investigasi lokal yang spesifik terhadap ketidakstabilan lereng dan tidak adanya data longsor akibat gempabumi yang menunjang, salah satu cara yang mungkin dapat ditempuh untuk menilai kerentanan bahaya longsor akibat gempabumi adalah dengan mengintegrasikan penginderaan jauh, sistem informasi geografis (SIG), analisis probabilitas bahaya gempabumi, dan mirozonasi berdasarkan Grade 2. Zonasi bahaya gempabumi di Baturagung didapatkan dari hasil analisis probabilistik menggunakan atenuasi Kanai. Informasi geologi didapatkan dari hasil interpretasi penginderaan jauh dengan bantuan peta geologi skala 1:100.000 lembar Yogyakarta dan peta geomorfologi daerah penelitian. Skoring dan overlay di dalam SIG digunakan untuk menerapkan model bahaya tanah longsor akibat gemabumi menurut Mora and Vahrson (1993). Peta hasil penilaian bahaya tanah longsor akibat gempabumi menunjukkan bahwa zona bahaya menengah hingga tinggi terdapat di bagian timur area penelitian, tepatnya di lereng bagian atas Baturagung. Area ini terletak diatas Formasi Semilir. Metode yang digunakan ini untuk selanjutnya dapat diterapkan sebagai penilaian awal dari investigasi lokal secara spesifik khususnya pada daerah yang dianggap penting dan bernilai tinggi. Metode ini juga dapat digunakan sebagai alat pengambilan keputusan yang sangat bermanfaat untuk mitigasi dan managemen bencana.
\end{abstract}

Kata Kunci: bahaya longsor Coseismic, sistem informasi geografis (GIS), Baturagung, penilaian bahaya 


\section{Introduction}

An earthquake defines as ground trembling caused by the sudden release of energy in the earth's crust. The energy can be from various sources such as tectonic deformation, volcanic eruption or even by man made activities (Elnashai and Sarno, 2008). A catastrophic earthquake can cause both primary and secondary hazard that potentially generate significant impact to human, infrastructure and environment. Ground motion and structural failure are known as the earthquake primary hazard that occur directly after the earthquake shock. Whereas the secondary hazard is post earthquake hazard caused by the primary hazards. Those hazards may often be more catastrophic which can cause huge casualties (Parise and Jibson, 2000). For example, tsunami, slope failure, landslide, tsunami, flood and dam failure.

One of the most important secondary hazard of earthquake is coseismic landslide (Jian Z, et al., 2010). The coseismic landslide can generate significant impact to human, physical infrastructure and environment. More than tens of thousands landslides were recorded between 1957-1999 as a result of 11 big earthquakes (Kefeer, 2002). Also, approximately 22,000 landslides were caused by 7.7 Richter scale of Chi-Chi earthquake in 1999 (Table 1). The coseismic landslides widespread occurred after Sinchuan earthquake (8.0 Ms) in Wenchuan, China. There were thousands of landslides, rock falls, debris flows and surface ruptures triggered by the earthquake (Huang et al. 2012b). Because of its widespread impact, the coseismic landslide hazard assessment need to be done in mountainous area that prone to the earthquake.

Indonesia is one of the most earthquake prone countries in the world. It is located at the junction of Indo-Australian plate, Eurasian plate and Pacific plate. According to Demets et al. (1994); Schluter et al. (2002) and Irsyam et al. (2010), the Indo-Australian and Pacific plates are moving, $7.23 \mathrm{~cm}$ per year northward and 11-12.5 cm per year westward respectively. Meanwhile, the Eurasian plate is relatively stable. This tectonic plate configuration is responsible for numerous earthquakes in Indonesia. More than 14,000 earthquakes of magnitude greater than $5 \mathrm{Mw}$ occurred between 1900 and 2009 with the most recent significant ones in Aceh, 2004 (Mw = 9.2); Nias, 2005 (Mw = 8.7); Yogyakarta, $2006(\mathrm{Mw}=6.3)$; Tasikmalaya, $2009(\mathrm{Mw}=$ 7.4); Padang, 2009 ( $\mathrm{Mw}=7.6$ ) and Kebumen, Central Java, $2014(\mathrm{Mw}=6.1)$

Table 1. Number of recorded coseismic landslides

\begin{tabular}{lccc}
\hline \multicolumn{1}{c}{ Location } & Date & Magnitude & $\begin{array}{c}\text { Number Of Coseismic } \\
\text { Landscape }\end{array}$ \\
\hline Daly City, California & 22 May 1957 & 5.3 & 23 \\
Guatemala & 4 Feb 1976 & 7.5 & $\sim 50.000$ \\
Mt. Diablo, California & 24 Jan 1980 & 5.8 & 103 \\
Mammoth Lakes, & 25 May 1980 & 6.2 & 5.253 \\
California & 2 May 1983 & 6.5 & 9.389 \\
Coalinga, California & 10 Oct 1989 & 5.7 & $>216$ \\
San Salvador, El Savador & 17 Oct 1989 & 6.9 & $\sim 1.500$ \\
Loma Prieta, California & 17 Jan 1994 & 6.7 & $>11.000$ \\
Northridge, California & 17 Jan 1995 & 6.9 & $674-747$ \\
Hyogen-Nanbu, Japan & 26 Sep 1997 & 6.0 & $100-124$ \\
Umbria Marche, Italy & 21 Sep 1999 & 7.7 & 22.000 \\
Chi-Chi, Taiwan & & & \\
\hline
\end{tabular}

Source: Keefer, 2002. 


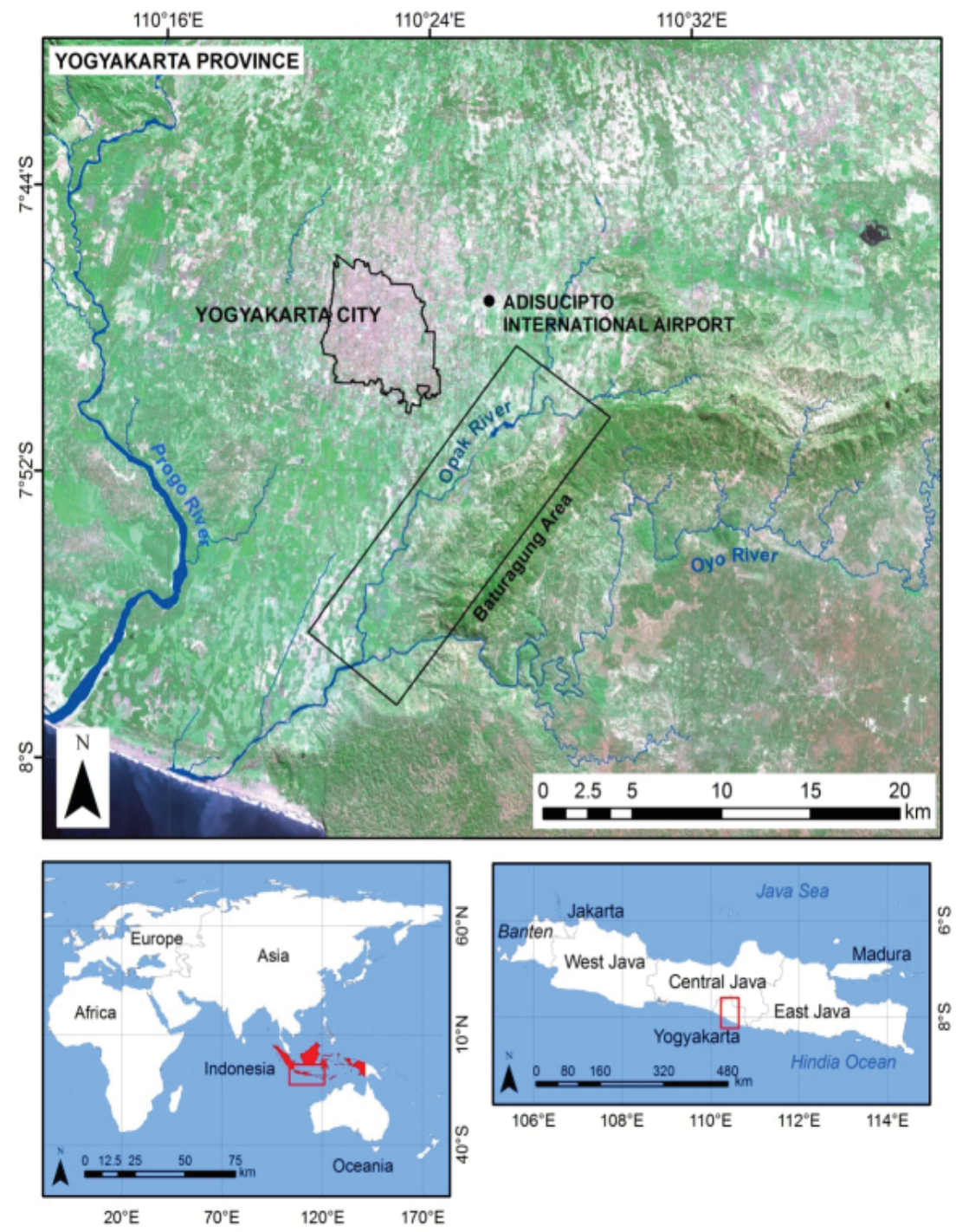

Fig.1 Map of Baturagung area

Located 250 km north of the Sunda Megathrust, Java is frequently hit by strong earthquakes. Additionally, it is the most densely populated island in Indonesia, with high frequency and intensity rainfall. This condition makes Java one of the most exposed regions for landslide occurrences especially in mountainous areas in the southern part of the island. A thousand landslides have been reported in Java from 1990-2005 and caused more than tens of thousands dollars of damages and loss (Hadmoko, 2010).

Baturagung area is located $8 \mathrm{~km}$ southeast of Yogyakarta City (Fig.1). In a complex topographical area, the western part is dominated by flat area with the lowest elevation of $7.96 \mathrm{~m}$, while the eastern Baturagung area is an undulating and very steep area. The highest elevation in the eastern Baturagung is $497.97 \mathrm{~m}$ above sea level (Fig. 2). Baturagung area has a humid tropical climate with seasonal monsoonal rainfall. The maximum rainfall usually occurs between February and September (Hamada et al., 2002). Based on the 1983-2003 rainfall data, the highest average of annual rainfall was 1,986 $\mathrm{mm}$ and the minimum of annual average rainfall was $1,801 \mathrm{~mm}$. 
Baturagung area can be divided into two main lithologies, i.e., the Miocene volcanic rock and the surface sediment deposits. The Miocene volcanic rock can be subdivided into Nglanggran Formation (Tmn) and Semilir Formation (Tmse), while the surface sediment can be subdivided into Alluvium (Qa) and Young Volcanic Deposits of Merapi Volcano (Qmi). Both Tmn and Tmse were formed from an ancient volcano located on the southern part of Yogyakarta Province. The Tmn and Tmse were formed in early Miocene and between late Oligocene-early Miocene respectively. The Tmn composed of volcanic breccia and lava flow containing breccia, agglomerate rock and tuff, while Tmse consists of interbedded tuff-breccia, pumice breccia, dacite tuff and andesite tuff, and tuffaceous clay-stone (Rahardjo et al., 1995) (Fig 2).

Tectonically Baturagung area is the part of Bantul's graben, which formed due to the tectonic uplifting process. The main active SW-NE fault, well known as Opak Fault, is located in the west of Baturagung area. It is a normal fault associated with the Opak River. The western area of Opak River is moving downward relatively, while the eastern part of Opak River is an uplift zone. Baturagung area is dominated by three major groups of landform originated from fluvial, denudation, and structural processes. The extensive fluvial landforms is located along the Opak River in the western part of Baturagung and in the narrow plain between the hilly areas in eastern part of Baturagung. The structural landform can be recognised from the topographical difference between the escarpment in the east and the subhorizontal area in the west. The denudation process occurs in the hilly areas in the east part of Opak River and steep areas (middle until upper slope) of Baturagung escarpment. The denudation zone is characterised as an extensive open area with less vegetation cover due to the traditional mining activities of breccia pumice. Because the high seismic activities and the high intensity of rainfall in Baturagung area, this area is very vulnerable to the coseismic landslide occurrence.

Two major methods to assess coseismic landslides have been developed such as the deterministic and statistical methods. The deterministic methods consist of pseudo-static methods or Newmark method or sliding block methods. It provides a detailed description of slope stability based on the stress variation due to the earthquake acceleration. This method has developed significantly since Newmark (1965) introduced the sliding block method (Sarna, 1975; Franklin and Chang, 1977; Yegian et al., 1991; Kramer and Smith, 1997; Bray et al., 1998; Rathje and Bray, 2000; Saygili and Rathje, 2008; Mehan and Vahedifard, 2013). Newmark's method presents a detailed natural slopes performance under the earthquake shocks. It provides a reasonable estimation of slope displacement caused by an earthquake. However, it uses several assumptions that might not appropriate with the real conditions (Jibson, 2007). 

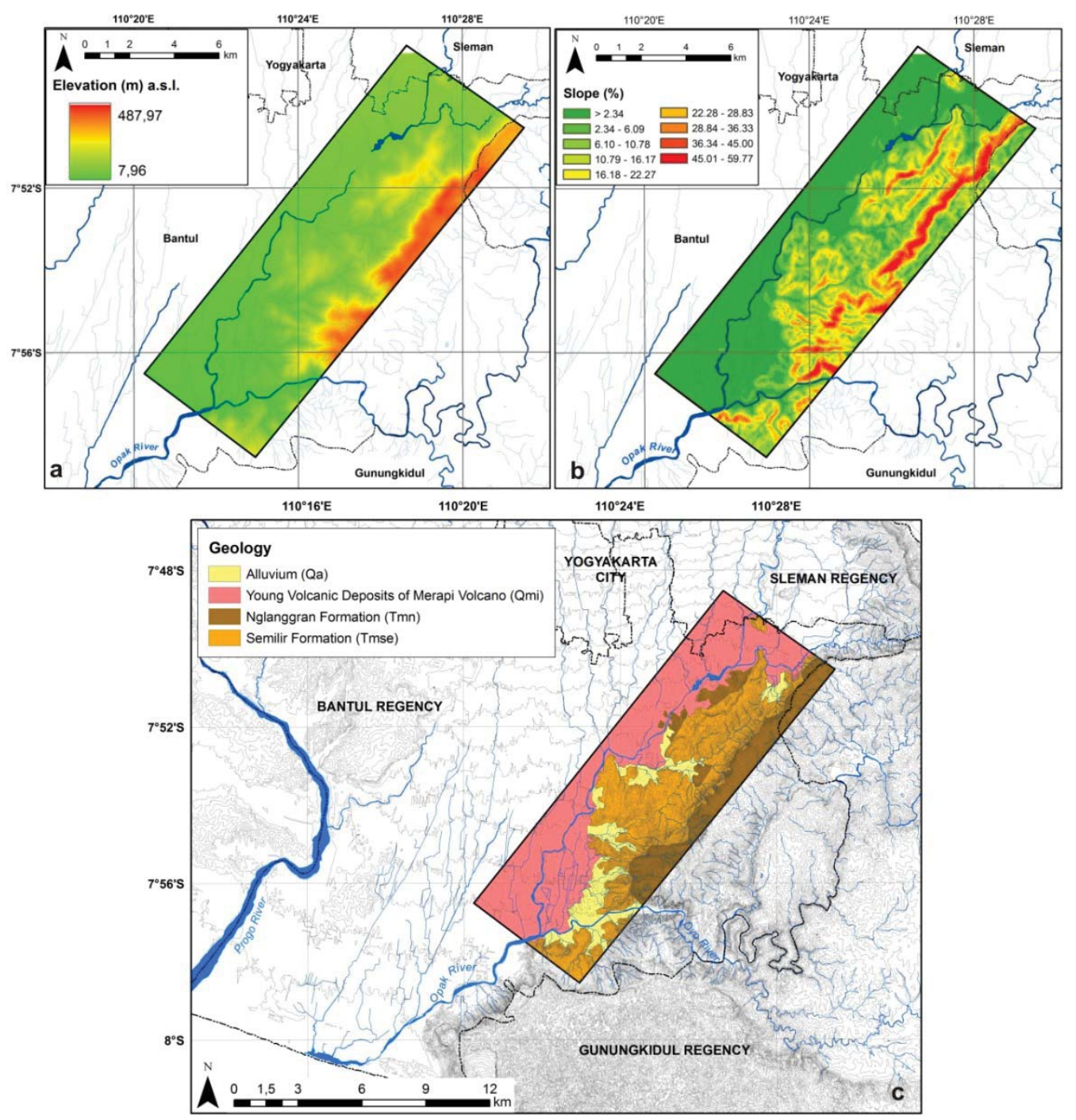

Fig. 2 (a) Elevation map; (b) slope map and (c) geology map of Baturagung area

The second method is statistical model. At the beginning of its development, it was used to evaluate and improve the Newmark's model. New statistical equation and attenuation based on the Newmark's model had been generated to assess coseismic landslide vulnerability such as Romeo, 2000; Jibson, 2007; and Jian et al., 2010. Other studies, such as Song et al., 2012; Umar et al., 2014 applied statistical model based on Bayesian network and integrated method of frequency ration (FR) and logistic regression (LR). The Bayesian network used to assess the coseismic landslide, while the FR and LR analysis used to determine the most important factor causing coseismic landslide. Since then, the statistical model has become an alternate method to assess the coseismic landslide vulnerability due to the flexibility of the input data determination. The statistical method gives also a good explanation the relationship among the different combination of used parameters. However, the statistical method gives indistinct results in regard of spatial distribution, moreover, the accurate data of existing coseismic landslide is highly required (Huang et al., 2012b).

With the capabilitiy of spatial analysis and rapid computational, remote sensing (RS) and geographic information sytstem (GIS) have successfully resolved the problem. Various methods ranging from the simplest method to a complex GIS model, either qualitative or quantitative model have been developed to assess the coseismic landslide vulnerability. Khanjai and Sitar (2003) used the GIS to 
analyse the coseismic landslide caused by Chi-Chi earthquake and concluded that the most significant triggering factor of Chi-Chi coseismic landslide was the ground motion. Miles and Keefer (2009) conducted analysis of how to combine the Newmark displacement method with the fuzzy logic system in GIS platforms, while Huang et al. (2012b) give a convincing result by combining the geomorphological characteristics and ground motion attenuation using GIS. In China, Meng et al. (2010) generated a coseismic landslide weight model through GIS analysis and was used for the basis reference of risk management and regional planning in Dujiangyan City. Another GIS based study was conducted by Umar et al. (2004) in West Sumatra Province, Indonesia. They used a combination of GIS analysis and statistical method to produce a rapid and accurate assessment of coseismic landslide disaster management and decision support making.

A microzonation method to assess the coseismic landslide has been developed by the Japanese Society of Soil Mechanics and Foundation Engineering in Japan. The method classifies the coseismic landslide into three categories, namely; Grade 1, Grade 2 and Grade 3. The Grade 1 is the general level of zonation with only analyse the earthquake magnitude and intensity. The rainfall data and geologic condition are often used as an additional input in this grade. Grade 1 is applicable for a 1:1,000,000-1:50,000 scale of mapping and very suitable for preliminary analysis at the provincial level (Ishihara and Nakamura 1987, Keefer and Wilson 1989). Grade 2 refers to a detailed method based on analyse of the historical data of earthquakes, rainfall patters, geological, and topographical data characteristics. It is suitable for a 1:100,000-1: 10,000 scale of mapping and often requires additional analysis on remote sensing, aerial photo and field observation data (The Technical Committee for Earthquake Geotechnical Engineering, TC4, 1993; Mora and Vahrson, 1993). A more detailed zonation of coseismic landslide can be obtained by applying Grade 3. It combines the Grade 1 and Grade 2 with additional analysis of site specific geotechnical investigation. The Grade 3 is very suitable for small area or a 1:25,0001: 5,000 scale of mapping (Newmark, 1965; Wilson et al., 1979; Tanaka, 1982; The Technical Committee for Earthquake Geotechnical Engineering, TC4, 1993.

Both seismic and landslide hazard assessment have been well developed in Southern Yogyakarta and its vicinity area including Baturagung area. Walter et al., 2007; Wagner et al., 2007; Burton and Cole, 2008; Burton et al., 2008; Haifani, 2008; Sulaeman et al., 2008; Abidin et al., 2009a and 2009b; Daryono, 2011; Hartantyo and Brontopuspito, 2012; Cahyaningtyas, 2012; Karnawati et al., 2012; Hadmoko, 2010; Priyono, 2012; Wacano and Hadmoko, 2012; Nugroho et al., 2012. However, the coseismic landslide hazard assessment has never been done before in Baturagung area. Therefore, the combination of RS and GIS based on the Grade 2 is very applicable in Baturagung area. It can generate the effective method of assessing coseismic landslide, which can minimise the effort and expense for further field investigation.

The application of RS, GIS, and PSHA based on the Grade 2 is very suitable for developing countries due to the data availability of coseismic landslide occurrences. Therefore, the combination method between RS, GIS and PSHA based on the Grade 2 of coseismic landslide microzonation is needed. The objective of this study is to assess and generate a coseismic landslide susceptibility map in Baturagung area, $8 \mathrm{~km}$ southeast Yogyakarta City, Indonesia.

\section{Research Method}

The integrated RS, GIS and probabilistic seismic hazard analysis (PSHA) was applied following the Mora Vahrson (1993) model to generate the coseismic landslide hazard model. The model analyses two main factors of coseismic landlsides: first, the susceptibility factors of coseismic landslides and seconds, the triggering factors of coseismic landslides. 
The model was developed for slope failure in Costa Rica, which is characterised as heavy rainfall and high seismic activities region. The similarity of physical characteristic between the Costa Rica and Indonesia especially Baturagung area and the data availability, make the Mora and Vahrson (1993) model very applicable in Baturagung area. Several parameters including relief, geology, humidity of the soil, seismic intensity and rainfall intensity were analysed using raster-based GIS and overlay method.

A GIS was used to generate the lithology index (st value) and the relief index ( $\mathrm{Sr}$ value). The soil humidity index and the rainfall intensity index (Sh and Tp value) was derived from a combination analysis between simple statistic analysis and thiessen polygons method in GIS. The Ts value or seismic intensity was generated from peak ground acceleration (PGA) using Kanai attenuation. The mathematical analysis using matlab software was done to obtain the Ts value. Finally, all of the parameters were rasterised and analysed based on the GIS platform.

\section{a. Parameters}

The analysis included five parameters, i.e., relief, lithology, oil humidity, seismic intensity, and rainfall intensity. A topographical map (1:25.000) with $12.5 \mathrm{~m}$ of contour interval was used to extract the slope. The relief condition was obtained from the slope analysis in GIS and classified into 7 categories based on the Van Zuidam (1985) classification. The lowest score of the relief is $0-75 \mathrm{~m} / \mathrm{km}^{2}$ and the highest score is $>800 \mathrm{~m} / \mathrm{km}^{2}$. The lowest category scored with zero (0) because it is assumed that a coseismic landslide will not occurs in flat to gently slop areas (relief: $0-75 \mathrm{~m} / \mathrm{km}^{2}$ or slope: $0-7 \%)$. The geologic information was extracted from the 1:100,000 geological map of Yogyakarta (Rahardjo, et al., 1995) and was validated using both the geomorphological map provided by Nurwihastuti (2008) and the interpretation results of ASTER imagery. The natural humidity index of soil was derived from the weighted value of summation of average monthly rainfall and the earthquake intensity was generated from the PSHA analysis using 3,481 earthquake data with magnitude greater than 5 Mw recorded by USGS between 1973 and 2014.

The attenuation equation followed the Kanai model (eq. 1 in Fig.3). This model was used because it includes the natural period of soil (Tg), which could amplify the ground motion during an earthquake. The dominant period of soil used in this study was obtained from the field measurement conducted by Daryono (2011). The rainfall data from 10 closed weather stations was used to analyze the average rainfall both monthly and annually between 1981 and 2013. Those kind of data were used to generate the value of soil natural humidity (Sh) and rainfall intensity (Tp) (Fig.3). Those tabular data were then converted into a vector format of GIS as the Thiessen polygons. The summary of parameters used can be seen in Fig.3.

\section{b. Coseismic landslide hazard assessment}

All of parameters were transferred into digital format using Arc GIS software. The raster based overlay analysis was applied in GIS platform using the equation 2 (Fig 3). The analysis results into six categories of susceptibility index, i.e., low, moderate, medium, high and very high area with the minimum value is 0 and the maximum value is 6,250 (Fig 3). 


\begin{tabular}{|c|c|c|}
\hline \multicolumn{2}{|c|}{ PARAMETERS USED } & \\
\hline \multicolumn{3}{|c|}{ Relief $\left(\mathrm{m} / \mathrm{km}^{2}\right)$} \\
\hline Classes & Susceptibility & Score \\
\hline $0-75$ & Very low & 0 \\
\hline $76-175$ & Low & 1 \\
\hline $176-300$ & Moderate & 2 \\
\hline $301-500$ & Medium & 3 \\
\hline $501-800$ & High & 4 \\
\hline$>800$ & Very high & 5 \\
\hline
\end{tabular}

Annual rainfall

("Summation value of average annual rainfall) Earthquake intensity $(\mathrm{Mm}) \mathrm{Tr}=100 \mathrm{yr}$. -

Rainfall intensity $(\mathrm{n}<10 \mathrm{yr}$, average $(\mathrm{mm}))$ Rainfall

\begin{tabular}{|l|l|l|l|l|}
\hline \multicolumn{1}{|c|}{ Classes } & Susceptibility & Score & Classes & Score \\
\hline$<50$ & Very low & 1 & $<125 \mathrm{~mm} / \mathrm{month}$ & 0 \\
$51-90$ & Low & 2 & $125-250 \mathrm{~mm} / \mathrm{month}$ & 1 \\
$91-130$ & Medium & 3 & $>250 \mathrm{~mm} / \mathrm{month}$ & 2 \\
$131-175$ & High & 4 & \\
$>175$ & Very high & 5 & \\
\hline
\end{tabular}

\begin{tabular}{|c|c|c|}
\hline $\begin{array}{l}\text { Summation } \\
\text { score }\end{array}$ & Susceptibility & Score \\
\hline $0-4$ & Very low & 1 \\
\hline $5-9$ & Low & 2 \\
\hline $10-14$ & Medium & 3 \\
\hline $15-19$ & High & 4 \\
\hline $20-24$ & Very high & 5 \\
\hline
\end{tabular}

\begin{tabular}{|l|l|l|}
\hline \multicolumn{1}{|l|}{ Intensity } & \multicolumn{1}{|c|}{ Susceptibility } & Score \\
III & Slight & 1 \\
IV & Very low & 2 \\
V & Low & 3 \\
VI & Moderate & 4 \\
VII & Medium & 5 \\
VIII & Considerable & 6 \\
IX & Important & 7 \\
X & Strong & 8 \\
XI & Very strong & 9 \\
XII & Extremely strong & 10 \\
& \\
& \\
& \\
& \\
& \\
& \\
& \\
& \\
\end{tabular}

Lithology

\section{Classes}

Permeable limestone, slightly fissured intrusions, basalt, andesites, granites, ignimbrite, gneiss, hornfels, low degree of weathering. Low water table, clean regose fracture, high shear strength rocks.

High degree of weathering of above mentioned lithologies and of hard massive clastic sedimentary rocks, low shear strength, shereable fractures.

Considerably weathered sedimentary, intrusive, metamorphic, volcanic rocks, compacted sandy regolithic soils, considerably fracturing, fluctuating water tables, compacted colluvium and alluvium.

Considerably weathered, hydrothermally altered rocks of any kind, strongly fractured and fissured, clay filled, poorly compacted pyroclastic and fluvio-lacustrine soils, shallow water table.

Extremely altered rocks, low shear resistance alluvial, colluvial and residual soils, shallow water table.

\begin{tabular}{|l|l|l|}
\hline Susceptibility & Score \\
\hline Low & 1 \\
Moderate & 2 \\
Medium & 3 \\
High & \\
\hline
\end{tabular}

\begin{tabular}{|c|c|c|c|}
\hline EQUATION & PSHA & $\alpha=\frac{\alpha 1}{T g} 10^{\operatorname{arm}-\log R+Q}$ & $\begin{array}{l}\alpha=\text { PGA } \\
\alpha 1=\text { Constant value }=5\end{array}$ \\
\hline & Eq.1 & $\begin{array}{l}P=1.66+\left(\frac{3.6}{R}\right) \\
Q=0.167+\left(\frac{1.83}{R}\right)\end{array}$ & $\begin{array}{l}\alpha 2=\text { Constant value }=0.6 \\
\mathrm{Tg}=\text { Natural period } \\
\mathrm{M}=\text { Magnitude } \\
\mathrm{R}=\text { Hypocentre }\end{array}$ \\
\hline
\end{tabular}

\begin{tabular}{|lll|c|c|}
\cline { 2 - 3 } \cline { 3 - 4 } Susceptibility & Class & \multicolumn{2}{l|}{ Value from Coseismic landslide equation } \\
\hline Negligible & I & $0-6$ \\
\hline \hline Low & II & $7-32$ \\
\hline \hline Moderate & III & $33-162$ \\
\hline Medium & IV & $163-512$ \\
\hline High & V & $513-1,250$ \\
\hline Very high & VI & $>1,250$ \\
\hline
\end{tabular}

Fig. 3 Parameters, equation used, and the result classification

\section{Result and Discussions}

The overall results seen in Figure 4 show that the methodology is capable to classify the Baturagung area into four categories of coseismic lanslide categories: negligible, low, moderate and medium zone. Negligible zones are the most stable and safe areas, characterised as very flat to gentle slope areas (0-8\%), located on the alluvial plain, colluvuim-alluvium footstep and natural levee. Geologically, it contains of undifferentiated 
volcanic rocks of Young Merapi Volcano and bad sorted alluvium, known as colluviums. The colluvial plain formed as a result of sedimentation process of denudations material from the mountainous areas in the eastern area. The other stable zone in study area is located on the summit of Baturagung escarpment which consist of the Nglanggran Formation. The total area of negligible zones is $71.18 \mathrm{~km}^{2}$ (59.78\%).

The low zone refers to border areas between flat area and mountainous in the eastern part. Most of them are on sloping areas (8$15 \%)$ near the rivers. The low zone donation extents in the lower slopes of strong eroded denudations hills of the Semilir Formation and residual hills of the Nglanggaran Formation. The building construction should be avoided, because the landslide body is often deposited in these areas, although they are relatively stable and safe zone. The total area of the low hazard zone is $4.02 \mathrm{~km}^{2}$ (3.38\%).
Coseismic landslide tends to occur in both moderate and the medium hazard zones. The moderate hazard is located in moderate until steep slopes, while the medium hazard is located in very steep slopes associated with upper slope of the Baturagung Escarpment. The moderate hazard is less vulnerable than the medium hazard with the hazard index of the moderate hazard is 33-162 (III) and the medium hazard is 163-512 (IV). Based on the geomorphological characteristic, both zones are distributed on the weak and strong eroded denudation mountain. it consists of interbedded tuff-breccia, pumice breccia, dacite tuff and andesite tuffs and tuffaceous clay stone, well known as Semilir Formation. Semilir Formation characterised as fractured weathered rocks with thin soil thickness due to the advance denudations process. The traditional mining of breccia pumice has created an extensive open area has led to the excessive. Approximately, $34.71 \%$ or $41.32 \mathrm{~km}^{2}$ of total study areaa are belongs to moderate zone and about $2.25 \mathrm{~km}^{2}$ (2.14\%) were categorized as the medium hazard zones.

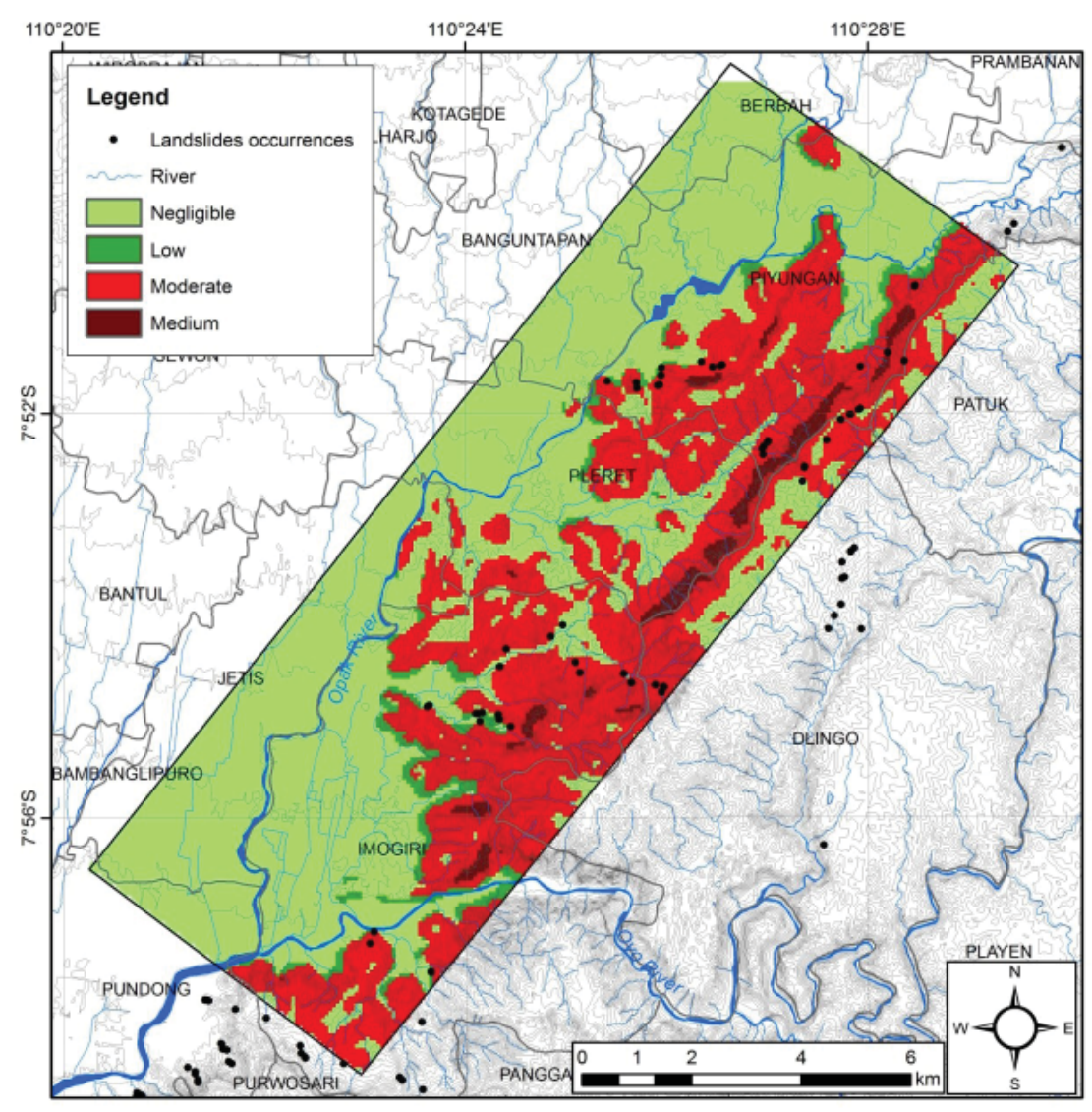

Fig. 4 Coseismic landslide vulnerability map of Baturagung area 
According to the historical data of landslide occurrences, most landslides occurred in moderat and medium hazard zone. When coseismic landslide occurs also in these zones, it will eventually bring the worst impact to the local people, because there are several fresh water springs, which is much needed to fulfil the daily needs of fresh water.

Administratively, Piyungan, Pleret, and Imogiri sub-district are susceptible to coseismic landslide. At least $10.78 \mathrm{~km}^{2}$ and $0.95 \mathrm{~km}^{2}$ area in Piyungan sub-district are categorised as moderate and medium vulnerability zone respectively. It is, therefore, at least 37.04 ha of settlement area with 76 inhabitants per hectare (BPS 2012) are in danger (Fig.4). Similar to Piyungan, the eastern part of Pleret Sub-District are vulnerable to coseismic landslide. At least $6.78 \mathrm{~km}^{2}$ of moderate hazard zones, and $0.75 \mathrm{~km}^{2}$ of medium hazard zones are located in the eastern part of Pleret Sub-district. At least 38.95 ha of residential houses are located in this zone. With the average population density of 74 people per ha, it means that more than 2,000 people are living with the high coseismic landslide risk.

The Imogiri Sub-district is special regions for the Yogyakarta Royal Circles. The royal cemetery, which is very valuable cultural heritage, is located in this area. According to Dinas Pariwisata Prov.DIY (2011), at least 635 of international tourist and 20,290 of local tourists visited this cemetery area in 2011. The cemetery complex is located 1.5 $\mathrm{km}$ downslope to the nearest medium hazard zones. With high population density (58 inhabitants per hectare) and one of the places frequented by tourist in Yogyakarta Province, Imogiri Sub-district become high risk area of cosesismic landslide.

The present study focuses on delivering semiquantitative method through the GIS platform to analyze the qualitative factors that might influence the coseismic landslide events. The semi-quantitative method is commonly used in Indonesia for single hazard assessment only such as landslide, earthquake, flood, et cetera, but it has never been used before for coseismic landslide hazard assessment in Indonesia.

Various methods have been developed worldwide to generate the coseismic landslide such as deterministic and statistical method. The deterministic method for example Newmark's model has been commonly used since 1965 , as well as the statistical method that developed for the Newmark's model improvement. Newmark's model can provide a detailed description of the slope performance during an earthquake. The statistical model is able to describe the relationship among the parameters used. However, Newmark's model give indistinct results of the spatial distribution. In the other word, Newmark's model is suitable only for site specific anises of slope performance during an earthquake. The statistical methods give an alternative to assess the coseismic landslide hazard, but it needs the accurate data of coseismic landslide events, which is not available in the study area.

The integrated RS, GIS and PSHA is suitable method to assess coseismic landslide in Baturagung area. An important feature of the GIS-based analysis used is their ability to overlap and relate the spatial information using various operators. This method will provide better spatial analysis of larger area with limited budget and time. Site specific investigation for example, is best suitable for 1: 5,000 scale of mapping. It requires detailed information of slope instability characteristic such as detailed topographic and slope data, cohesion of soil information, internal friction angle of the layer and the thickness of the sliding layer. In Indonesia, for detailed topographic survey take an average of 3.5 million rupiahs per hectare. Applying the site specific investigation to research area (1: $100,000)$ is generally very expensive.

This study combined the RS, GIS, PSHA and Mora and Vahrson (1993) model and gave four different coseismic landslide susceptibility zones. The results give a clear description of coseismic landslide microzonation in Baturagung area, but the quality of the results 
depend very much on the quality of the input data and the results is unable to describe the uncertainty of the dynamic process based on the Newtonian model like pseudo-static analysis. However, the model has a good ability to explain the spatial pattern, which is important to support the local and regional authorities on risk reduction and disaster management. Moreover, this model can be used as a reference for future studies of coseismic landslide assessment in Indonesia due to the absence of the standard procedure for assessing the coseismic landslide hazard.

Indonesia is very prone to coseismic landslide hazard due to its physical characteristic and the seismic activities. This also potentially amplifies the number of damage and victims due to the unavailability of the implementation of disaster mitigation planning. This problem should become the primary topic of the future research in Indonesia. An integrated multidisciplinary of science needs to be involved in this topic. Risk analysis, lands planning, building codes, mitigation planning and early hazard education are all significant topics to support an integrated coseismic landslide hazard management. It is recommended that this study be adopted or extended to other areas in Indonesia, which have the similar characteristic of the study area.

\section{Conclusion}

The present contribution has demonstrated the importance of coseismic landslides to the southeast of Yogyakarta City. It has been recognised as the hazards triggering the highest number of disaster in Central Java and around the world. Various coseismic landslides model have been developed since Newmark (1965) explained the sliding block method. Although the Newmark's model provides a detailed description in regard to the slope displacement during the earthquake shock, such model is not well adapted to explain the spatial distribution of coseismic landslide. The usage of integrated method between remote sensing, geographic information system and probabilistic seismic hazard analysis based on the Grade 2 of coseismic microzonaton has provided a better description of the spatial distribution of coseismic landslide vulnerability.

Using this integrated method, four categories of coseismic landslide vulnerability have been drawn: negligible, low, moderate, and medium zones. The most stable and safe area, or negligible zone is located on the flat and gentle slope (0-8\%). The vulnerability index in this zone range between 0 and 6 . It is associated with the alluvial plain, colluvial plain, mountain foot slope, and natural levee. The higher vulnerability index between 7-32 is located along the border between the eastern mountainous area and the extensive flat area in the West. Most of these hazardous areas are located on sloping angles of $8 \%$ to $15 \%$ and very close to the rivers. The middle slope of strong and weak eroded denudation hills of the Semilir Formation are dominated by the moderate zone. It consists of interbedded tuff-breccia, pumice breccia, dacite tuff and andesite tuffs and tuffaceous clay stone, which is very unstable. The highest score of coseismic landslide vulnerability is located in the upper slope of Baturagung area. These areas are defined as the most unstable and susceptible to coseismic landslide.

Interestingly, one of the Yogyakarta tourism sites, Royal cemetery of Yogyakarta Kingdom, is located in moderate zone of coseismic landslide. It means this area is very prone to coseismic landslide event. The specific site analysis needs to be done in this area because it is very valuable for the cultural heritage of Yogyakarta. The early education on seismic hazard and its secondary hazard are absolutely needed for local people who live in western flank of Baturagung area. The result shows that more than 8,000 people are living with high coseismic landslide risk in Imogiri, Pleret and Piyungan Sub-District.

The future site specific investigation or higher 
order of coseismic landslide microzonation is very important for important place such as the Royal cemetery of Yogyakarta Kindom. There is still also a need for further research to better help the modifications and improvements in order to obtain better results of coseismic landslides hazard zonation.

\section{Acknowledgement}

The authors would like to acknowledge The Indonesia Endowment Fund For Education (LPDP) for financial support, as well as the University of Canterbury New Zealand who provided adequate reference for this project.

\section{References}

Abidin HZ, Andreas H, Kato T, ItoT, Meilano I, KimataF, Natawidjaja DH, HarjonoH (2009a) Crustal deformation stuides in Java (Indonesia) using GPS. Journal of Earthquake and Tsunami3(2) : $77-88$

AbidinHZ, Andreas H, Meilano I, Gamal M, Gumilar I, Abdullah CI (2009b) Deformasi koseismik dan pascaseismik gempa Yogyakarta 2006 dari hasil survei GPS. Jurnal Geologi Indonesia4(4): 275-284

BrayJD, Rathje EM, AugelloAJ, Merry SM (1998) Simplified seismic design procedures for geosynthetic-lined, solid waste landfills. Geosynthetic and Geoenvironmental Engineering 133 (4): 381-392.

BurtonPW, Cole SW (2008) Development towards the seismic hazard mapping of Javain the Yogyakarta earthquake of May 27, 2006, eds. D Karnawati, S Pramumijoyo, R Anderson, S. Husein. Star Publishing Campany, Inc., Belmont, CA: 10-1 - 10-13

BurtonPW, WeatherillG, Karnawati D, Pramumijoyo S (2008) Seismic hazard assessment and zoning in Java: New and alternative probabilistic assessment models. International Conference on Earthquake Engineering and Disaster Mitigation.

Cahyaningtyas DR (2012) Studi kerawanan seismik Kecamatan Temon, Wates, dan Panjatan, Kabupaten Kulonprogo. M.Sc. Thesis, Geo Information for Spatial Planning and Risk Management. Universitas Gadjah Mada Yogyakarta, Indonesia.

Daryono (2011) Indeks kerentanan seismik berdasarkan mikrotremor pada setiap satuan bentuklahan di zona Graben Bantul Daerah Istimewa Yogyakarta. Dissertation, Program Pascasarjana Universitas Gadjah Mada Yogyakarta

DemetsCR, GordonD, Argus, Stein S (1994) Effect of recent revisions to the geomagetic reversal time scale on estimates of current plate motions. Geo-phys. Res. Lett (21): 2191-2194.

Dinas Pariwisata Prov. DIY (2011) Statistik kepariwisataan 2011. Dinas Pariwisata Provinsi Daearh Istimewa Yogyakarta.

Franklin, AG, Chang, FK (1977) Earthquake resistance of earth and rockfill dams. Misc. Paper S-17-17. U.S. Army Waterway Experiment Station, Vickburg, Miss.

HadmokoDS(2010) Landslide hazard and risk assessment and their application in risk management and landuse planning in easrtern flank of Menoreh Mountains, Yogyakarta Province, Indonesia. Nat. Hazards (54): 623-642.

HaifaniAM (2008) GIS application on micro-seismic hazard analysis in Yogyakarta Province. MSc Thesis, UGM-ITC. 
Hamada J, Yamanaka MD, Matsumoto J, Fukao S, Winarso PA, Sribimawati T (2002) Spatial and temporal variations of the rainy season over Indonesia and their link to ENSO. Journal of the Meteorological Society of Japan80(2): 285-310.

HartantyoE, Brotopuspito KS (2012) The estimation of PGA, PGV, and PGD values in Jogjakarta area, Case Study Jogja Earthquake 2006 (2012) Proceeding of National Seminar in Remote Sensing and Geographic Information System 2012. Muhammadiyah University of Surakarta, Central Java

Huang Y, Chen CY, WuTH, Chang CL, LiuSY, Kao CY (2012b) GIS-based evaluation on the fault motion-induced coseismic landslides. J. Mt. Sci. (9): 601-612

IshiharaK, Nakamura S (1987) Landslides in mountain slopes during the Ecuador earthqauke of March 5, 1987. US-Asia Conference on Engineering for Mitigating Natural Hazards Damages.

Irsyam M, Sengara IW, Aldimar F, Widiantoro S, Triyoso W, Natawidjaja DH, Kertapati E, Meilano I, Suhardjono, AsrurifakM, Ridwan M 2010. Ringkasan Hasil Studi Tim Revisi Peta Gempabumi Indonesia. Bandung.

JeburMN, Pradhan B, Tehrany MS (2013) Detection of vertical slope movement in highly vegetated tropical area of Gunung pass landslide, Malaysia, using L-band InSAR technique. Geosci. J. 1-8.

Jian Z, Peng C, BingkunZ, Changwei Y, McVerry GH (2010) Earthquake-induced landslide displacement attenuation models and application in probabilistic seismic landslide displacement analysis. Earthquake Engineering and Engineering Vibration9: 177-187.

JibsonRW (2007) Regression models for estimating coseismic landslide displacement. Engineering Geology 91: 209-2018.

KarnawatiD, Ibriam I, Anderson MG, Holcombe EA, Mummery GT, Renaud JP, Wang Y (2004) An initial approach to identifying slope stability control in Southern Java and to providing community-based landslide warning information. In Glade, T Anderson, M Crozier MJ (eds.) Landslide hazard and risk. Wiley, London, pp 733-763.

Keefer DK (2002) Investigating landslides caused by earthquakes - a historical review. Surveys in geophysics $23: 473-510$.

Keefer DK (2013) Landslides generated by earthquakes: Immediate and long-term effects. Treatise on Geomorphology5: 250-266.

KeeferDK, Wilson RC (1989) Predicting earthquake-induced landslides with emphasis on arid and semi-arid environments. Publication of the Inland Geological Society2: 118-149

KhanjaiB, Sitar N (2003) Evaluating of factors controlling earthquake-induced landslides caused by Chi-Chi earthquake and comparison with the Northridge and Loma Prieta events. Engineering Geology 71: 79-95

Kramer SL, Smith MW (1997) Modified Newmark model for seismic displacements of compliant slopes. Journal of Geotechnical and Geoenvironmental Engineering 123 (7): 653-644.

Meehan CL, Vahendifard F (2013) Evaluation of simplified methods for predicting earthquakeinduced slope displacements in earth dams and embankments. Engineering Geology 152: 180-193. 
Meng W, Jianping Q, Siming HE (2010) GIS-based earthquake-triggered landslide hazard zoning using contribution weight model. J. Mt. Sci. 7: 339-352

Miles SB, Keefer DK (2009) Evaluation of CAMEL - Comprehensive Areal Model of earthquake-induced landslides. Engineering Geology 104: 1-15

MoraS and VahrsonW (1993) Microzonation Methodology for Landslide Hazard Determination. Bull. Intl. Ass. Eng. Geology, in press

NewmarkNM (1965) Effects of earthquake on Dams and Embankments. Geothecnique 15 (2): $139-160$

Nugroho ES, Hadmoko DS, van Westen C, Kingma N (2012) Analyzing and estimating the impact of landslide to road in Samigaluh District, Kulon Progo Regency.Forum Geografi26 (2): $132-145$

Nurwihastuti DW (2008) Integrasi Pemrosesan Citra ASTER dan Sistem Informasi Geografis Untuk Kajian Geomorfologi Studi Kasus di Sebagian Daerah Istimewa Yogyakarta. M.Sc. Thesis. Fakultas Geografi UGM, Yogyakarta

Parise M, Jibson RW (2000) A seismic landslide susceptibility rating of geologic units based on analysis of characteristic of landslides triggered by the 17 January, 1994 Northridge, California earthquake. Eng Geol 58 (3-4): 251-270.

PradhanB, Lee S (2010) Regional landslide susceptibility analysis using back-propogation neural network model at Cameron Highland, Malaysia. Landslides 7: 13-30.

Priyono KD (2012) A study of clay mineral in occurrences of landslide disaster area at Kulonprogo Mountains Yogyakarta Special Province. Forum Geografi 26 (1): 53-64.

RahardjoW, Sukandarrumidi, Rosidi HMD (1995) Geological Map of the Yogyakarta Sheet, Jawa. Geological Research and Development Centre, Bandung Indonesia.

RathjeEM, Bray JD (2000) Nonlinear coupled seismic sliding analysis of the earth structures. Journal of Geotechnical and Geoenvironmental Engineering 126 (11): 1002-1014.

Romeo R (2000) Seismically induced landslide displacements: a predictive model. Engineering Geology 58: 337-351.

SarnaSK (1975) Seismic stability of earth dams and embankments. Geotechnique 25 (4): 743761.

SaygiliG, Rathje EM (2008) Empirical predictive, models for earthquake-induced sliding displacement of slopes. Journal of Geotechnical and Geoenvironmental Engineering 134 (6): 790-803.

Schluter HU, Gaedicke C, Roaser A, Schreckenberger B, MeyerH (2002) Tectonic features of the southern Sumatra- western Java forearc of Indonesia. Tectonics21(5): 1047.

SongY, Gong J, Gao S,Wang D, Cui T, Li Y, Wei, B (2012) Susceptiility assessment of earthquake-induced landslides using Bayesian network: A case study in Beichuan, China. Computers \& Geosciences 42: 189-199.

Sulaeman C, Dewi LC, Triyoso W (2008) Karakterisasi sumber gempabumi Yogyakarta 2006 berdasarkan data GPS. Jurnal Geologi Indonesia3 (1): 49-56.

Tanaka K (1982) Seismic slope stability map. Journal of Japan Landslide Society51 (8) pp. 662-672. 
The Technical Committe for Earthquake Geotechnical Engineering, TC4, of The International Society for Soil Mechanics and Foundation Engineering (ISSMFE) (1993) Manual for zonation on seismic geothecnical hazards. The Japanese Society of Soil Mechanics and Foundation Engineering. Tokyo Japan.

Umar Z, Pradhan B, Ahmad A, Jebur MN, Tehrany MS (2014) Earthquake induced landslide susceptibility mapping using an integrated ensemble frequency ratio and logistic regression models in West Sumatra Province, Indonesia. Catena 118: 124-135.

Van Zuidam RA (1985) Aerial photo interpretation in terrain analysis and geomorphologic mapping. Smith Publisher: The Hague.

Wacano D, Hadmoko DS (2012) Pemetaan kerawanan longsorlahan di Daerah Aliran Sungai (DAS) Tinalah Kulon Progo. Proceeding of National Seminar in Remote Sensing and Geographic Information System. Muhammadiyah University of Surakarta, Central Java

Wagner D, Koulakov I, Rabbel W, Luehr BG, Wittwer A, Kopp H, BohmM, Asch G, MERAMEX Scientist (2007) Joint inversion of active and passive seismic data in Central Java. Geophys. J. Int.170: 923-932.

Walter TR, Wang M, Zimmer H, Grosser B, Luehr, RatdomopurboA (2007) Volcanic activity influenced by tectonic earthquake: Static and dynamic stress triggering at Mt. Merapi. Geoph. Research Leters 34, L05304.

Wilson R, Eieczorek G, Harp E (1979) Development of criterio for regional mapping of seismic slope stability. 1979 Annual meeting of the Geological Society of America.

Yegian MK, Marciano EA, Ghahraman VG(1991) Earthquake-induced permanent deformations: probabilitic approach. Journal of Geotechnical Engineering 117 (1): 35-50.

Yin J, Chen J, Xu X, Wang X, Zheng Y (2010) The characteristics of the landslides triggered by the Wenchuan Ms > 8.0 earthquake from Anxian to Benchuan. J. Asian Earth Sci. 37: 452-459. 